Alicante Journal of English Studies 25(2012): 57-66

\title{
History and Poetry in William Shakespeare's Lucrece
}

\author{
Krystyna Kujawińska Courtney \\ University of Lodz \\ miranda@uni.lodz.pl
}

\begin{abstract}
This essay demonstrates the interrelationship between the historical source (Livy, Ab Urbe Condita LVIII-LX) and the literary source (Ovid, Fasti, II. 721-852) present in the construction, or rather, in "the artistic scheme," of Shakespeare's Rape of Lucrece. The "Argument," written in prose and the text of the narrative poem reveal Shakespeare's synchronic engagement with both Clio and Calliope. The synergistic interaction between the two parts proves that Shakespeare either consciously or unconsciously joined the ongoing discussion on the interaction between history and poetry. Falling in line with the sixteenth-century debate on the credibility of historical sources, the reading of Lucrece encourages the reader to judge the so-called authenticity or actuality of past events as depicted in different genres of literary texts. In other words, as a two-part structure Shakespeare's Lucrece invites the analysis of the relationship between history/historiography and poetry, in which one of the essential elements is the question of the process of interpreting both historical and poetic narrative texts and their use of language, style, form and literary genre.
\end{abstract}

Even a cursory look at historical works written during Shakespeare's times shows that the problem of their credibility constituted one of the major topics of discussion among contemporary luminaries of science, culture and literature (Baker, 1967: 15-41). Although the majority of them attributed a particularly important place to history, claiming proudly that it is thanks to history that the true image of the world is accessible, Philip Sidney mocked the pretentiousness and bombast of the historian's 
profession. He maintained that a person occupied with history is usually an oldfashioned pedant, "“'loden with old Mouse-eaten records [. . .], a wonder to young folkes and a tyrant in table talke," who refers incessantly to Cicero in order to prove his or her erudition, and protests "in a great chafe, that any man for teaching of vertue, and vertous actions, is comparable to him." First of all, "this buffoon," as the poet calls the historian later in the same work - An Apologie for Poetrie- (1579, published 1595) has no grounds for attributing erudition to himself, for his knowledge limits itself mainly to plagiarisms or works based on "the notable foundation of hearsay," most often full of errors and modifications. Moreover, his study method — as we would call it today - belittles the value of the created work, since the historian shows "not to what should bee but to what is, to the particular truth of things and not to the general reason of things" (Sidney, 1904: 162, 164).

Although Sidney's critical comments do not express the general opinion of the Elizabethan philosophy of history, they do present two very important issues. In those times it was believed, following the ancients, that the main purpose of historical works was to determine and declare the truth about past events, and that this truth should play the role of a moral paradigm for relationships between people, confirmed by the experience of eminent individuals. Therefore, history - in contrast to other types of writing - was meant to tell the truth as well as to give useful advice on living in society. An attitude to history is expressed by Richard Stanyhurst, who wrote in Holinshed's Chronicles of England, Scotland, and Ireland that history is "the marrow of reason, the creame of experience, the sap of wisdome, the pith of judgement, the librarie of knowledge, the kernell of policie, the unfoldresse of treacherie, the kalendar of time, the lanterne of truth, the life of memories, the doctresse of behaviour, the register of antiquitie, the trumpet of chivalrie." Even if some Elizabethan humanists, Sidney among them, had serious reservations about the two prerogatives of history, truth and moral usefulness, most of them believed this topic to be so important that they incessantly analyzed the purposes and methods of the philosophy of history. Shakespeare was already a participant in these debates at the beginning of his career, as the narrative poem Lucrece testifies. ${ }^{1}$

When writing his Lucrece, Shakespeare used two sources: the first book of AbUrbe Condita or Books from the Foundation of the City, published also under the title History of Rome, particularly chapters LVIII-LX, written by Titus Livius (Walsh, 1966: 115-142), and Ovid's Fasti: On the Roman Calendar, 721-852, a very popular poetic work in sixteenth-century England (Miola, 1983: 20). ${ }^{2}$ Even though the events described in these works are nowadays regarded as legends or myths (all archive materials concerning the history of Rome before 390 B.C., that is the First Gallic Invasion, having been destroyed), when Shakespeare was writing they were thought to be historical facts. The respect with which the works of Livy and Ovid were treated in sixteenth-century Europe was greatly influenced by the indisputable authority of their authors. This issue is discussed, among others, by Warren Chernaik (2011: 25-33), who points out that Shakespeare had to work with two stylistically different narrations of Lucrece's story. Using accessible official documents, including decrees of the senate as 
well as diplomatic and army correspondence, Livy set Lucrece's story against a wide sociopolitical background, retaining a historian's distance in his prose. The poetic version of the events, proposed by Ovid, has above all - even if this is primarily because of the genre - an emotional character: it captures mostly Lucrece's and Tarquin's psychological and emotional states (Cousin, 2000: 49-58).

This ideologically and stylistically differential interpretation of historical events found its reflection in Shakespeare's Lucrece, to which its structure contributes significantly. The work is composed of two parts: the Argument, written in prose, and the text of the narrative poem. ${ }^{3}$ Analysis of the mutual relationships between these parts, as I shall try to prove, supports the thesis that the use of this particular structure allowed Shakespeare, either consciously or unconsciously, to participate in this debate on the interactions between history and poetry (or a literary work in general). Some scholars claim, however, that the Argument was not actually written by Shakespeare, as -in their opinion - its prose, "stiff and artificial" (Talbot, 1950: 75), is radically different from the prose used by him in many of his dramas. This view was definitely undermined by Peter Hyland, who pointed out that the prose used in Shakespeare's plays always performs the function of characterizing the dramatis personae (2003: 106).

The process of comparing the sources used by Shakespeare in creating the greater part of his dramatic works, and not only the ten plays about the history of England, proves that the multiplicity of interpretations of historical facts was not unknown to him. In fact the entire professional life of the poet was an experimentation with ways of translating history into dramatic form (Kujawinska Courtney, 1997: 16-26). The richness of historical facts and their interpretations in the sources available to Shakespeare must have inspired the poet to reflect on which of them should be chosen for the literary work that was to be created, and which should be omitted. It is enough to mention here historians' conflicting opinions about the reign of Richard III, opinions to which Shakespeare had access through source literature (including chronicles, Mirror of Magistrates and various literary works). The assertion present in the concluding Chorus to Henry $V$, saying that drama is a collection of characters' deeds, mangling by starts the full course of their glory" (4) is -in my opinion- one of the instances in which Shakespeare overtly commented on the method of translating historical sources into literary form. ${ }^{4}$

Writing Lucrece was his first serious attempt at applying this method, the more so as the two principal sources used by Shakespeare - History of Rome and Fasti- differ from one another regarding the representation of the facts and the characterization of the dramatis personae. For instance, Livy's narration, referring to the tyranny of King Tarquin the Proud and describing the systemic changes that took place in Rome after Lucretia's suicide, situates the tragedies against a wide historical background. Ovid's text mainly presents the emotions of the principal characters, particularly of Lucretia, and devotes much space to authorial reflections and comments. Combining these two texts, Shakespeare's narrative poem provided a perspective on two conceptions of 
history, as can be seen in the styles used, one formal and one emotional and behaviourist.

Although prima facie the Argument seems merely to fulfill the function of a summary preceding the main content of the work, a comparative analysis of its text with the text of the poem reveals that the relationship between them significantly influences the interpretation of the work. On the one hand, the Argument, showing not only the tyranny of King Tarquin the Proud, which has an unquestionable influence upon the sexual tyranny of the King's son, but also the punishment received, accords with a providential vision of history. The fall of the house of Tarquin is just and even desired, since it is accompanied by the restoration of order to the world. On the other hand, commencing in medias res, the content of the poem Lucrece oscillates between narration and drama. This, together with its almost laconically short ending, imitates, on the narrative level, the arbitrariness accompanying the causality of the events happening in the life of its heroine. If, however, the behaviour of the main figures is linked to the values of the society in which they are living, the poetic part of the work illustrates that the motivations involved are more complex than indicated by the emotionless prose of the Argument. It is the combination of interactions between inclinations and desires present in a given culture that is primarily responsible for human behaviour.

The poem's most significant divergence from the content of the Argument is its political dimension: about one fifth of the text of the Argument is devoted to politics, whereas in the poetic part these issues occupy no more than a few lines. The information given in the Argument is one of the factors that allow readers to become conscious of the relationship between the family's predisposition to tyranny and the behaviour of Sextus Tarquinius, as well as the political effects of his crime. We learn that his father, Lucius Tarquinius, "for his excessive pride surnamed Superbus, after he had caused his own father-in-law Servius Tullius to be cruelly murdered, and, contrary to the Roman laws and customs, not requiring or staying for the people's suffrages, had possessed himself of the kingdom" (Argument, lines 1-5). The poem, on the other hand, only makes a brief reference to the fact that Sextus Tarquinius is his "proud issue" (37), of which Lucrece is aware, in receiving her "princely guest" (90) at night, with appropriate honours. These quite laconic references to his kingly position become, however, the main argument of her requests that he should refrain from the planned rape. Nevertheless, there is no mention here of Tarquin's family connections, for in her supplications Lucrece appeals only to princely honour.

Moreover, the last stanza of the poem omits the removal of the Tarquin dynasty from the throne and the establishment of the Roman Republic. Using facts present in both Livy's and in Ovid's work, Shakespeare writes in the Argument alone that after Brutus had delivered "a bitter invective against the tyranny of the King", the Romans "were so moved, that with one consent and a general acclamation the Tarquins were all exiled, and the state government changed from kings to consuls" (Argument, 38-40). In the poetic version of these events, Brutus, using connotations of the word "Rome" five times in one stanza (1828-1834), calls for Lucrece's death to be avenged. However, he mentions neither Tarquin's father nor changing the political system. The poem's 
conclusion states that only Tarquin/the rapist has been exiled from the city: "The Romans plausibly did give consent / To Tarquin's everlasting banishment" (18541855).

The poetic version gives precedence to the personal dimension of the events, presenting the story as a tale about the tragedy of a woman - a rape victim, woven into Realpolitik. Beginning the poem in the midst of the action, when "From the besieged Ardea all in post, / Borne by the trustless wings of false desire, / Lust-breathed Tarquin leaves the Roman host" (1-3) and sets off for Rome in order to pay Lucrece a night visit, Shakespeare radically shortens the initial historical context. With the betting episode omitted, Tarquin's desire is not born at the sight of Lucrece during his previous visit, as presented in the Argument, but is caused by the description of her beauty given by her husband. The narrator questions Collatine's behaviour: "Or why is Collatine the publisher / Of that rich jewel he should keep unknown / From thievish ears, because it is his own?" (33-35). It is as if he were suggesting that Collatine himself could be judged complicit in the rape.

The translation of Lucrece's suffering into the literary form of the "lament" also constitutes an interpretation of her attitude to history. She cannot see the forwardreaching effects of the rape from a political perspective: she perceives revenge - the accomplishment of which will depend on nothing more than men's courage - only in personal terms. Furthermore, she interprets the fall of Troy in a similar way. The painting, and especially the figure of Hecuba, strengthens her complaint caused by her own suffering and the suffering of others, but without provoking the thought of Aeneas's restoration of the city's power. This attitude to history, based on grievances, intensifies past unhappiness and past tragedies, without providing hope for a better future. It shows the limited needs of an individual rather than the nation's widely understood mission. Conferring upon Lucrece this particular attitude to history translates the passive role of women in political and social life so typical both in antiquity and in the Elizabethan era, into the language of poetry. Barbara Babcock claims that although women play a "central" role in the Rome created by Shakespeare, they are situated on the "social peripheries" (1978: 32). Their centrality is related to their biology, and - more specifically - their sexuality, whereas it was the boundaries of domus that did not allow them to appear on the public forum. In contrast to this stance is the epic or heroic reading of history by Brutus: rejecting the "dew of lamentations" (1829) and attempting instead to sooth and even completely relieve the pain by the use of force (1829). This attitude to history also requires breaking with the passive role of the victim for the benefit of aggressively shaping one's own fate and the fate of the nation. This kind of attitude to history can be justified by the interpretation of historical causality in the categories of divine providence, or - as in the case of Brutus - by assigning oneself the power to shape the future.

The depiction of the emotional states of the main characters, that is of Tarquin and Lucrece, constitutes one of the most visible differences between the Argument and the poem. In the former there are short, obvious observations, such as "Lucrece, in this lamentable plight" (Argument, 25), whereas the poem abounds with extensive 
fragments capturing the characters' psychological states. Hence, Tarquin is constantly struggling with himself, analyzing the psychology of his motives, and Lucrece is trying to cope with the increasing feeling of injustice and shame, which she perceives in personal and social terms. This specific psychomachia was rendered by Shakespeare in extensive monologues giving the details of each of the particular characters' reasoning, especially in the moments preceding the rape and the suicide, respectively. This device reveals a common truth: private matters always have a public and social dimension.

In other words, the poetic retelling affects the readers' emotions, not only through the description, but also by provoking lacrimae rerum, whereas the prosaic version of the Argument is inseparably bound to intellectual perception, teaching us that all authority based on tyranny will meet due punishment. Although a cursory reading of Lucrece may give the impression that it is this part of the work that is the source of unquestioned historical truth, its interpretation in the context of the poem reveals the omissions and half-truths concealed within it. Examples of these are, among others, the lack of reference to Brutus's earlier hypocrisy, and his political manoeuvring after Lucrece's death, which cast doubt on his moral engagement not only in the revenge, but also in the matter of changing the system of government. All things considered, a comparison of the prosaic and poetic versions of the events undermines the initial belief in the objectivity of the Argument as an example of historical documentation.

Paying equal attention to both forms of discourse, that is to historical prose and to poetry, Shakespeare's work alerts the reader to interpretational traps connected with the literary form of discourse. The Argument introduces a wide historical background, but it omits the personal motivations of the main characters' actions. On the other hand, although the text of the poem is inseparably connected with the ethical dimension of their behaviour, such as complicating the reason why Brutus calls for revenge after Lucrece's death, it is unable to reveal the political perspective within the wider historical context as the prose does. Undoubtedly, both historical prose and historical poetry are governed by their own laws, but in both cases a crucial role is played by the choice of facts, the decision where to begin and where to end the sequence of events and the omission or development of the events' complexity. Lucrece's suicidal death might seem to be an exceptionally propitious moment to end a poem. This literary work, however, culminates with political upheaval. The poem Lucrece alerts readers to the fact that even if the selection of accessible source materials is mainly based on intuition alone, it undoubtedly influences the interpretation of the events they depict.

Moreover, creative interpretation of history, as Shakespeare proves in his work, is also affected by the choice of vocabulary and poetic form. Both the beginning and the ending of the poem draw attention to the meaning of the word "publish" (33), which in the sense of "public announcement" exerts an influence not only upon the individual, but also upon the life of a nation. The "publishing" of Lucrece's virtues by Collatine leads to her rape and suicide, and the "publishing" of Tarquin's dishonour constitutes a prelude to the change in the system of government. In the poem, there are also many references to various ways in which narration can capture past events. For instance, seeking Lucrece's favour and trust, Tarquin praises her husband's courage (106), thus 
making use of hyperbolic flattery. On the other hand, Lucrece's fears that her tragedy shall become the subject of ballads or tales for children indicate that narrative forms have a fundamental influence upon the interpretation of past events. ${ }^{5}$

One of the leading motives of the poem is "reading," or - more precisely"deciphering" / "interpreting" the texts as understood in a cultural sense. And so, for example, as Tarquin creeps to Lucrece's bedroom he is unable to properly interpret nature's ominous signs that warn him against committing the crime (323-26). Neither are his comrades-in-arms nor King Tarquin the Proud able to see through Junius Brutus's hypocrisy, whose mask is feigned mental retardation. And it is Lucrece who makes the greatest number of interpretative mistakes. She incorrectly interprets Tarquin's facial expression when he suddenly appears at her house at night. Furthermore, in the morning, when she is giving the servant a letter addressed to Collatine, she is convinced that she sees the knowledge of her rape written on the servant's face. Reflecting upon the social response to her humiliation and shame (81012), Lucrece attempts to persuade herself to commit suicide in order to be "the mistress of [her] fate" (1069). Her fate will become a text that will not "publish", but punish.

The fact that the main part of Lucrece is occupied by a narrative poem can be regarded as proof of privileging poetry, which was propagated by Sidney in Apologie for Poetrie:

Compare we the Poet with the Historian, and with the Morrall Philosopher, and if, hee goe beyond them both, no other humaine skill can match him. For as for the Diuine, with all reuerence it is eurer to be excepted, not only for hauing his scope, as afr beyonde as any of these as eternite exceedeth a moment, but euen for passing each of these in themselves. (16)

This assertion is, however, a simplification. Both the Argument and the body of the poem record only selected elements of the story (Brandt, 1993: 22-32). Both, above all, present the author's creative capacities to translate complicated and complex source material, which cannot be subject to unequivocal interpretation, into the form of a limited transcript.

To a certain degree, Shakespeare explains the artistic credo of his work in the description of the fall of Troy shown in the picture:

For much imaginary work was there, -

Conceit deceitful, so compact, so kind,

That for Achilles' image stood his spear

Gripp'd in an armed hand; himself behind

Was left unseen, save to the eye of mind:

A hand, a foot, a face, a leg, a head

Stood for the whole to be imagined.

$(1422-1428)$

In demonstrating the way in which the painter had been able, by means of details, to capture the epic quality of the events, Shakespeare adduces a synecdoche that is to aid 
in understanding the connection between historical sources and a literary work - a narrative poem in this case - created on the basis of these sources. These relationships and subsequent dependencies are founded on selecting the proper episodes, zooming in on them and setting them in the appropriate historical context. Only by means of analyzing the parts presented by histories can one reach an understanding of the past's complexity, and yet this complexity will never allow one to see the whole picture. The use of a two-part structure for Lucrece strengthens the impression that Shakespeare acknowledged these imperfections when translating the complicated interpretative mosaic present in the poem's sources into artistic language. It is a mistake to regard the Argument as a miniature of the poem, as it undoubtedly constitutes an indispensable part. Michael Pratt seems to be right in calling it "a prose envelope, but an envelope indicating how we are to understand the poetical letter inside it" (1983: 20).

The two-part structure of Shakespeare's Lucrece also becomes an inspiration for the analysis of the relationship between history/historiography and poetry, in which one of the essential elements is the question of the process of interpreting narrative texts and their use of language, style, form and literary genre. By reconsidering the customary priority of historical/"true" (as based on facts) narration, present in the Argument, Shakespeare's work demonstrates that poetical narration does not guarantee historical credibility either, even if it may be due to the genre dimension pertinent to it. It is also worth paying attention to the problem of the lack of faith in any historical narration, including chronicles, scholarly recordings, political pamphlets, eulogies, as well as calumnies, and literary texts written in all possible genres. As usually happens in Shakespeare's works, the author asks questions, but does not give any explicit or unequivocal answers. Moreover, falling in line with the sixteenth-century debate on the credibility of historical sources, the reading of Lucrece encourages us to judge the socalled authenticity or actuality of past events as depicted in different genres of literary texts, paying attention to the fundamental significance of narrative, stylistic and linguistic interdependencies.

\section{Notes}

1. The extended title The Rape of Lucrece did not appear before the 1616 edition. Since it was the year of the poet's death, it is not known whether he knew about the title change. In Shakespeare's day, there were two functioning orthographies of the name: "Lucrece" and "Lucretia." For a further explanation of this subject see Kujawińska Courtney (2011: 29-40).

2. Shakespeare would have also been familiar with the versions of Lucrece's story presented by Geoffrey Chaucer in The Legends of Good Women (1680-1885) and by William Painter in The Palace of Pleasure (1566), cited by Geoffrey Bullough in his monumental work Narrative and Dramatic Sources of Shakespeare (1957: 179-199). Livy's work is, however, not mentioned among the excerpts from the works given by Bullough since, according to the critic, "the dramatist seems to have had before him a copy of Titus Livy's History of Rome (Chapters LVII-LX), represented here by the fairly close version made by Painter for his Palace of Pleasure (1566)" (179). Bullough also believes also that "[t]hroughout Shakespeare is expanding Ovid's brief account [...], and filling out the outline of the Roman's sophisticated 
simplicity with long disquisitions on the physical and emotional states of the two main figures [Lucrece and Tarquin] as they occur, disquisitions conducted with ritualistic stylization as the contrast between virtue and vice, innocence and lust, hospitality and betrayal, is enforced with rhetorical antithesis and paradox" (1957: 180).

3. It is only in Lucrece that Shakespeare made use of an Argument, which in those times played the role of an extended summary. Plays such as Romeo and Juliet, Henry V, Troilus and Cressida, Henry VIII and Two Noble Kinsmen open with a Prologue, which summarizes the plot and sets the scene for the events about to take place. In the romance Pericles this task is fulfilled by Gower, an actual character. A different device is used in The Tempest, in which the story preceding the drama is told by Prospero, one of the main characters of the play, although not at the beginning but in the course of the action (1.2.66-187). There is also the Induction in The Taming of the Shrew, in the form of a short play preceding the main plot and referring to the subject of the drama (Kujawińska Courtney, 1990: 137-151).

4. The problem of the difficulties met by literary authors seeking to represent historical events in a literary form constitutes the subject-theme of many scholarly works. See Hayden White (1973: 5-6).

5. In his dramatic works, Shakespeare returned to the issue of relating the fate of eminent individuals in forms that diminish their tragedies. Just before committing suicide Cleopatra fears that "saucy lictors/ Will catch at us like strumpets, and scald rhymers / Ballad us out o' tune. The quick comedians / Extemporally will stage us, and present / Our Alexandrian revels: Antony / Shall be brought drunken forth, and I shall see / Some squeaking Cleopatra boy my greatness / I' the posture of a whore." (Antony and Cleopatra, 5.2.213-219).

\section{References}

Babcock, Barbara (1978): The Reversible World: Symbolic Inversion in Art and Society. Ithaca: Cornell University Press.

Baker, Herschel (1967): The Race of Time: Three Lectures on Renaissance Historiography. Toronto: University of Toronto Press.

Brandt, E. Bruce (1993): "Shakespeare's The Rape of Lucrece: Argument, Text, and Interpretation." In J. Ruud, ed., Proceedings of the First Dakotas Conference on Earlier British Literature. Aberdeen, South Dakota: Northern State University Press, 22-32.

Bullough, Geoffrey, ed. (1957): Narrative and Dramatic Sources of Shakespeare. London: Routledge and Kegan Paul, Vol. 1.

Chernaik, Warren (2011): The Myth of Rome in Shakespeare and His Contemporaries. Cambridge: Cambridge University Press.

Cousin, A.D. (2000): Shakespeare's Sonnets and Narrative Poems. Harlow, England: Longman.

Hyland, Peter (2003): An Introduction to Shakespeare's Poems. Palgrave.

Kujawińska Courtney, Krystyna (1997): Królestwo na scenie: Sztuki Szekspira o historii Anglii w teatrze angielskim. Lodz: Wydawnictwo Uniwersytetu Lódzkiego.

- (2011): "Shakespeare's The Rape of Lucrece: Preliminary Survey of Its Literary and Dramaturgical Appropriations". In A. Weseliński, ed., Anglica: Literature and Culture in Context. Warszawa: Wydawnictwo Uniwersytetu Warszawskiego, 29-40.

Miola, Robert (1983): Shakespeare's Rome. Cambridge: Cambridge University Press. 
Platt, Michael (1983): Rome and Romans According to Shakespeare. Lanham, New York, London: University Press of America.

Sidney, Philip (1904): “An Apologie for Poetrie.” In G. Gregory Smith, ed., Elizabethan Critical Essays. Oxford: Oxford University Press, Vol. 1.: 1-193

Shakespeare, William (1962): Antony and Cleopatra. The Arden Shakespeare. M. R. Ridley, ed. London: Methuen and Co. Ltd.

(1964): King Henry V. The Arden Shakespeare. J. H. Walter, ed. London: Methuen and Co. Ltd.

(1982): The Poems. The Arden Shakespeare. F.T. Prince, ed. London: Methuen and Co. Ltd. All quotations of the poem are from this edition.

Stanyhurst, Richard (1807-1808): Holinshed's Chronicles of England, Scotland, and Ireland. Vol. vi, sig. b4r

Walsh, P. G. (1966): “Livy.” In T. A. Dorey, ed., Latin Historians. London: Routledge and Kegan Paul, 115-142.

White, Hayden (1973): The Historical Imagination in Nineteenth-Century Europe. Baltimore and London: The Johns Hopkins UP. 